\title{
Analisis Kinerja Keuangan Terhadap Pertumbuhan Laba Pada Perusahaan Makanan dan Minuman yang Terdaftar di Bursa Efek Indonesia Tahun 2013-2017
}

\author{
Yuni Utari ${ }^{1}$, Ridwan $^{2 *}$ \\ 1,2Program Studi Akuntansi, STIE Bhakti Prasetya Karya Praja, Jakarta \\ $2^{2}$ coresponding author's email: ridwan.8900@gmail.com
}

\begin{abstract}
AbstrakPertumbuhan perusahaan menjadi faktor penentu dalam konteks berinvestasi. Perusahaan makanan dan minuman menjadi kategori industri yang sangat strategis khususnya di Indonesia. Sektor ini juga menjadi penyumbang terbesar Produk Domestik Bruto (PDB) dalam kurun waktu beberapa tahun. Penelitian ini bertujuan untuk menganalisis kinerja keuangan yang terdiri dari rasio cepat, rasio utang terhadap ekuitas, total perputaran aset, margin laba bersih secara parsial terhadap pertumbuhan laba perusahaan sub sektor makanan dan minuman yang terdaftar di BEI periode 2013-2017. Penelitian ini termasuk jenis kuantitatif.Sumber data yang digunakan adalah data sekunder berupa laporan keuangan tahunan perusahaan. Teknik sampling yang digunakan adalah purposive sampling, dan sampel sebanyak 11 perusahaan makanan dan minuman. Metode analisis data menggunakan statistik deksriptif, analisis regresi data panel, dan uji asumsi klasik. Hasil penelitian menunjukkan pertumbuhan laba dapat dipengaruhi secara simultan berdasarkan rasio cepat, rasio utang terhadap ekuitas, total perputaran asset secara positif, dan margin laba bersih dengan kontribusi sebesar 13,26\% dan 86,74\% dijelaskan variabel di luar variabel yang diteliti. Hasil uji parsial hanya membuktikan total asset turnover atas rasio aktivitas memiliki pengaruh positif dan signifikan terhadap pertumbuhan laba.
\end{abstract}

Kata kunci: Rasio Keuangan, Pertumbuhan Perusahaan, Perputaran Total Aset.

\section{Pendahuluan}

Pertumbuhan perusahaan menjadi faktor penentu dalam rangka investor dalam berinvestasi.Pertumbuhan perusahaan yang pesat menjadisuatu peluang yang diharapkan investor di masa mendatang sehingga menarik perhatian kepada investor. (Septian, 2016). Perusahaan sektor aneka industri yaitu kategori makanan dan minuman adalah salah satu jenis di Bursa Efek Indonesia (BEI) yang berpotensi secara berkesinambungan untuk berkembang.Semakin banyaknya industri makanan dan minuman di wilayah Indonesiaakan 


\section{Buana Akuntansi}

Yuni dan Ridwan

Vol. 5 No. 2

ISSN 2528-1119

E-ISSN 2580-5452

diprediksi akan semakin membaik sejak memasuki krisis berkepanjangan. Kondisi ini menjadikan semakin ketatnya tingkat persaingan sehingga para manajer sebagai akan berkompetisi untukmencari investor agar berinvestasi di perusahaan pada sektor ini(Kementerian Perindustrian RI 2017).

Sejak tahun 2017, industri makanan dan minuman menjadi kategori industri yang sangat strategis dan mempunyai prospek yang bagus untuk dikembangkan. Tidak heran, di kala industri lain melambat pertumbuhannya, industri makanan dan minuman naik lebih kencang. Sektor ini atas Produk Domestik Bruto (PDB) menjadi penyumbang terbesar dan pada industri non-migas yang mencapai $34,33 \%$. Di samping itu, dengan pertumbuhan sebesar 9,23\% atau meningkat dibandingkan dengan pertumbuhan tahun 2016 sebesar 8,46\%(Kementerian Perindustrian RI 2017). Selanjutnya, nilai atas ekspor produk makanan dan minuman tercatat di angka USD31,7 miliar di tahun 2017 termasuk didalamnya minyak kelapa sawit, sehingga neraca perdagangan mengalami peningkatan yang positif dibandingkan dengan nilai impor pada periode yang sama atas produk makanan dan minuman sebesar USD 9,6 miliar.Jika dilihat dari perkembangan investasi sektor industri makanan dan minuman di tahun 2017, dengan realisasi mencapai Rp 38,54 triliun untuk Penanaman Modal Dalam Negeri (PMDN) dan Penanaman Modal Asing (PMA) sebesar USD 1,97 miliar (Endarwati 2018)

Peningkatan PDB mencerminkan adanya peningkatan daya beli konsumen yang menyebabkan bertambahnya atas permintaanbarang dan jasa dari masyarakat yang pada akhirnyaakanmencapai laba perusahaan yang tinggi (Kewal 2012). Menyadari dampak signifikan dari laba terhadap kinerja perusahaan, manajemen perusahaan akan selalu berusaha mengelola laba yang dilaporkan. Harga pasar secara eksplisit dipengaruhi oleh faktor laba perusahaan, spekulasi investasi dan tingkat risiko. Perusahaan yang secara konsisten mengalami peningkatan laba setiap periodenyaakanberdampakpada penurunan risiko yang lebih besar jika dibandingkan dengan persentasepeningkatan laba. Kondisi ini berdampak padasemakin banyaknyapengaturan laba dalam upaya mengurangi risiko tersebut(Natalia dan PudjoLaksono 2013).

Penelitian ini mereviu beberapa temuan penelitian terdahulu yang menguji pengaruh WCTA, OITL, TAT, ROA, dan ROE terhadap pertumbuhan laba 40 industri manufaktur di BEI tahun 2010-2014 menggunakan analisis regresi linier berganda. Temuan penelitian menunjukkan bahwa variabel Operating Income to Total Assets (OITL), ROA (Return On Asset), dan ROE (Return On Equity) memiliki pengaruh yang signifikan pada pertumbuhan laba dengan arah positif sementara variabel Working Capital to Total Asset (WCTA), dan Total Asset Turnover (TAT) tidak memiliki pengaruh yang signifikan atas pertumbuhan laba. Kelima variabel yang diuji (WCTA, OITL, TAT, ROA dan ROE) berpengaruh secara simultanatas pertumbuhan laba (Erawati dan Widayanto 2016). Penelitian yang menguji pengaruh dari rasio profitabilitas dan likuiditas atas pertumbuhan laba 16 perusahaan manufaktur periode 20102012 menggunakan regresi data panel. Temuan penelitian menunjukkan bahwa keseluruhan variabel yang terdiri dari current ratio, quick ratio, cash ratio, gross profit margin, return on asset dan return on equity tidak berpengaruh secara signifikan atas pertumbuhan laba (Khaldun dan Muda 2014).

Penelitian yang menguji pengaruh kinerja keuangan atas pertumbuhan laba yang melibatkan 14 perusahaan food dan beverage periode 2010-2015 menggunakan analisis regresi berganda. Temuan penelitian menunjukkan bahwa variabel NPM memiliki pengaruh yang 


\section{Buana Akuntansi}

Yuni dan Ridwan

Vol. 5 No. 2

ISSN 2528-1119

E-ISSN 2580-5452

positif dan signifikan atas pertumbuhan laba sedangkan variabel CR, TATO, DER tidak berpengaruh secara signifikan pada pertumbuhan laba (Djannah 2017). Penelitian yang menguji pengaruh Quick Ratio, Debt to Equity Ratio, Inventory Turnover, dan Net Profit Margin atas Pertumbuhan Laba yang melibatkan 13 Perusahaan Manufaktur di BEI tahun 2011-2015 juga menggunakan metode regresi linier berganda. Temuan penelitian menunjukkan bahwa Quick ratio, debt to equity ratio, dan inventory turnover tidak berpengaruh secara signifikan atas pertumbuhan laba sementara net profit margin berpengaruh signifikan dengan arah positif atas pertumbuhan laba (Ayem, Wahyuni dan Suyanto 2017).

Pentingnya penelitian ini untuk menguji atas faktor-faktor pengukuran kinerja keuangan yang terdiri dari Quick Ratio, Debt-to Equity Ratio, Total Asset Turnover, dan Net Profit Margin yang berdampak pada pertumbuhan laba. Perbedaan ini dengan penelitian terdahulu yaitu penelitian ini menggunakan subjek penelitian pada perusahaan sektor aneka industri sub sektor makanan dan minuman dan menggunakan periode 2013-2017. Penelitian ini tetap mengoperasikan variabel kinerja keuangan yang sama dengan penelitian-penelitian terdahulu. Pertumbuhan laba diukur berdasarkan proksi profit growth.

\section{Tinjauan Pustaka}

2.1. Teori Sinyal

Teori sinyal (signalling theory) diperkenalkan pertama kali melalui penelitian Spencer yang berjudul Job Maret Signaling pada tahun 1973. Teori pensinyalan menjelaskan bahwa perusahaan terdorong untuk menginformasikan kepada pihak eksternal berupa laporan keuangan perusahaan. Dorongan untuk memberi informasi karena munculnya asimetri informasi antara pihak manajemen dengan pihak eksternal (Malau dan Parhusip 2016). Teori sinyal mengemukakan tentang perusahaan yang seharusnya menyampaikan laporan keuangan dalam bentuk sinyal-sinyal kepada para pengguna. Sinyal ini berupa informasi realiasi atas keinginan investor atas aktivitas yang telah diupayakan oleh pihak manajemen. Teori sinyal mengurangi adanya asimetris informasi dimana manajer selaku yang mewakili pihak manajemenuntuk memberikan informasi prospek perusahaan yang berbeda dengan investor, investor dan pihak manajemenberupaya dan yang sama atau simetris. Sinyal ini menyatakan bahwa perusahaan akan lebih baik dibandingkan dengan perusahaan lainnya dalam bentuk seperti promosi atau informasi lainnya (Kusumastuti, Setiawati dan Bawono 2016).

\subsection{Kinerja Keuangan}

Quick Ratio (QR) adalah rasio yang mengukur kemampuan membayar utang dengan aset lancar dengan tidak memperhitungkan nilai perusahaan.Quick ratio merupakan rasio yang berfungsi dalam memenuhi kewajiban yang akan jatuh tempo untuk melihat kemampuan jangka pendek perusahaan melalui aset yang sangat likuid (Hery 2015, 154). Debt-to Equity Ratio (DER) merupakan adalah salah satu rasio solvabilitas yang merefleksikan jumlah pendanaan utang dalam struktur modal suatu perusahaan (Subramanyam 2014, 565), DER menunjukkan seberapa mampu kewajiban dapat ditutupi oleh modal perusahaan, dimana semakin rendah rasio utang semakin baik karena menjamin keamanankepada kreditor saat dilikuidasi (Fahmi 2017). Semakin tinggi nilai DER maka akansemakin memperkecil modal perusahaan yang dijadikan jaminan utang atas pemilik. Ketentuan umumnya adalah bahwa debitor seharusnya 


\section{Buana Akuntansi}

memiliki debt-to equity ratio kurang dari 0,5 namun perlu diingat juga bahwa ketentuan ini tentu saja dapat bervariasi tergantung pada masing-masing jenis industri.Total Assets Turnover (TAT) merupakan rasio yang mengukur perbandingan atas jumlah penjualan bersih dengan total aset. TAT merupakan rasio aktivitas yang mengukur penjualan yang dihasilkan berdasarkan kepemilikan aset perusahaan sebagai kemampuan perusahaan (Mahaputra 2012). TAT digunakanuntuk mengukur efektivitas dari keseluruhan aset perusahaan dalam menghasilkan penjualan atau mengukur penjualan yang akandiperoleh dari setiap kuantiti dalam dana yang tersedia dalam total aset dalam satuan rupuah (Hery 2015, 187). Net Profit Margin (NPM) yaitu rasio untuk digunakan perusahaan untuk memperoleh laba bersih dari omset penjualan sebagai ukuran kemampuanperusahaan. NPM dapat dinyatakan sebagai persentase atas sisa setiap hasil penjualan setelah dikurangi dengan keseluruhan biaya, termasuk beban bunga dan pajakperusahaan (Munte dan Sitanggang 2015). Perbandingan atas total laba bersih dengan total pendapatan perusahaan digunakan untuk mengukur NPM dan mengetahui optimalisasi laba yang diperoleh perusahaan. Semakin tinggi rasio NPM, pendapatan yang dihasilkan atau laba yang tinggi dan begitupun sebaliknya (Azmi, Andini dan Rahar 2016).

\subsection{Pertumbuhan Laba}

Laba merupakan bentuk informasi yang paling dinanti oleh para investor dalam konteks pasar uang. Laba usaha yang ditentukan pada periode tertentu merupakan tujuan utama dalam pembuatan laporan laba rugi (Subramanyam 2014, 4). Menurut IAI (2009), laporan laba rugi menjadi acuan penting untuk menjalankan fungsi penyediaan informasi akuntansi berupa Penyusunan Laporan Keuangan dengan mengacu pada Standar Akuntansi Keuangan (SAK) serta mendorong penetapan regulasi pemerintah terkait sistem finansial yang menjamin pelaksanaan good corporate governance. Di sisi lain, bagi pihak manajemen dapat mengaplikasikan dan metode akuntansi tertentu yang paling menguntungkan (Husain dan Surachman 2017), misalnya dengan teknik estimasi manajemen laba yang merupakan bagian dari pendekatan untuk mengindentifikasi pertumbuhan laba guna memberikan informasi kepada pihak eksternal. Laporan laba rugi juga dapat menggunakan pengukuran analisis rasio keuangan untuk melihat sejauh mana suatu perusahaan memiliki kinerja keuangan baik dan benar dengan menggunakan aturan-aturan tersebut (Fahmi 2017, 239, Yanti, Isyanto dan Mohd Saudi 2020).

Perhitungan pertumbuhan laba dihitung dengan cara mengurangkan laba periode saat ini dengan periode sebelumnya dibagi laba periode sebelumnya (Harahap 2016). Laba seringkali dijadikan ukuran untuk menilai keberhasilan kinerja perusahaan.Informasi laba sangat berguna dalam memprediksi dan mengestimasi pertumbuhan laba, karena sangat berguna dalam mengevaluasi kebijakan-kebijakan yang telah dirumuskan pihak manajemen serta ditujukan kepada investor yang ingin menginvestasikan modalnya.Pertumbuhan laba dapat dipahami sebagai kenaikan laba yang diperoleh dalam satuan persentase. Pertumbuhan laba positif mengindikasikanbahwa perusahaan telah memanfaatkan sumber daya untuk dapat mengelola dan menghasilkan laba sertahasil kinerja keuangan (Rachmawati 2014).

\subsection{Pengembangan Hipotesis}

Laba menjadi output penting untuk mengukur pertumbuhan perusahaan. Output ini digunakan untuk menilai hasil kinerja keuangan yang diukur menggunakan paramater rasio 


\section{Buana Akuntansi}

Yuni dan Ridwan

Vol. 5 No. 2

ISSN 2528-1119

E-ISSN 2580-5452

keuangan. Hasil penelitian yang menguji quick ratio $(\mathrm{QR})$ dengan temuan tidak membuktikan pengaruhnya secara signifikan atas pertumbuhan perusahaan (Khaldun dan Muda 2014, Ayem, Wahyuni dan Suyanto 2017). Pentingnya quick ratio yang merupakan aset lancar yang likuid hendaknya menjadi alat untuk menagih dalam rangka pemenuhan kewajiban dan mengevaluasi kebijakan manajemen, dimana semakin cepat rasio ini maka pendapatan yang diperoleh akan semakin tinggi dan mengakibatkan pertumbuhan laba juga akan meningkat. Hipotesis alternatif ini dirumuskan:

$\mathrm{H}_{1}$ :Quick ratio berpengaruh positif atas pertumbuhan laba

Suatu rasio solvabilitas yang merefleksikan jumlah utang atas modal yang diteliti melalui pengukuran debt-to equity ratio (DER) dengan temuan tidak membuktikan pengaruhnya secara signifikan atas pertumbuhan perusahaan(Ayem, Wahyuni dan Suyanto 2017, Djannah 2017). Semakin tinggi tingkat utang, perusahaan akan memperoleh sumber pendanaan dalam rangka peningkatan profitabilitas walaupun juga memiliki risiko yang tinggi. Hipotesis alternatif ini dirumuskan:

$\mathrm{H}_{2}$ :Debt-to equity ratio berpengaruh positif atas pertumbuhan laba

Total asset turnover (TAT)yang menggambarkan aktivitas perusahaan atas suatu capaian dalam penjualan merupakan refleksi bentuk kemampuan perusahaan yang pada penelitian terdahulu tidak membuktikan pengaruhnya secara signifikan atas pertumbuhan perusahaan (Erawati dan Widayanto 2016, Djannah 2017). TAT yang semakin tinggi dalam mengukur efektivitas dari keseluruhan aset perusahaan juga menandakan efektifnya manajemen perusahaan dalam memperoleh pendapatan yang juga berdampak pada pertumbuhan laba. Hipotesis alternatif ini dirumuskan:

$\mathrm{H}_{3}$ :Total asset turnover berpengaruh positif atas pertumbuhan laba

Net Profit Margin (NPM) yang menggambarkan aktualisasi penjualan untuk mengukur kemampuan perusahaan dalam mencapai profitabilitas yang pada penelitian terdahulu membuktikan pengaruhnya secara signifikan atas pertumbuhan perusahaan(Djannah 2017). Selanjutnya dengan pengukuran operating income to total assets (OITL) yang mengindikasikan bahwa perputaran aset yang cepat akan menunjang kegiatan penjualan bersihnya sehingga meningkatkan perolehan laba(Erawati dan Widayanto 2016). NPM juga memiliki pengaruh yang tidak signifikan atas pertumbuhan yang berarti pencapaian laba operasional dalam rangka meningkatkan usaha tidak dapat dicapai (Ayem, Wahyuni dan Suyanto 2017). NPM yang semakin tinggi dinilai memiliki kemampuan perusahaan dalam laba operasional yang juga berdampak pada pertumbuhan laba. Hipotesis alternatif ini dirumuskan:

$\mathrm{H}_{4}$ :Total asset turnover berpengaruh positif atas pertumbuhan laba

Berdasarkan hasil pengembangan hipotesis beberapa penelitian terdahulu, maka diperlukan suatu model penelitian. Model digunakan oleh praktisi untuk mendeskripsikan suatu masalah yang nyata menjadi sebuah bangunan dalam proses pengambilan keputusan (Sharda, Delen dan Turban 2013, 8). Lebih lanjut, pemodelan adalah segala sesuatu yang dibangun berbasis parameter spesifik dalam konstruk yang dibatasi berupa struktur, bentuk, isi, angka, dan makna (Husain, T. 2019). Model penelitian ini dapat dirumuskan sebagai berikut: 


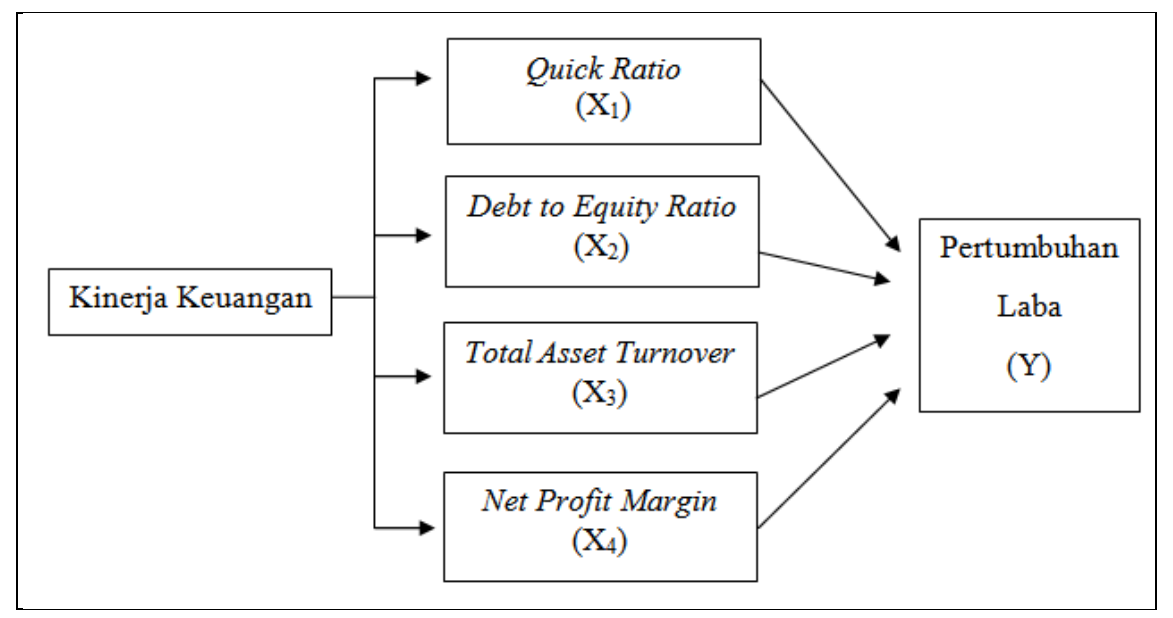

Gambar 1: Model Penelitian

\section{Metodologi Penelitian}

\subsection{Jenis Data Penelitian}

Jenis penelitian ini merupakantahapan atau cara ilmiah untuk memperoleh data dengan kegunaan dan tujuan tertentu merupakan definisi dari metode penelitian (Sugiyono 2018, 2). Pendekatan kuantitatif dipilih pada penelitian ini karena melibatkan data berupa angka-angka yang tertuang dalam laporan keuangan perusahaan. Jenis penelitian yaitu riset kausalitas.Penelitian dilakukan di Bursa Efek Indonesia (BEI) yang beralamat di Gedung Bursa Efek Indonesia, Tower 1 - Lantai 6, Jl. Jend Sudirman Kav. 52-53, Jakarta Selatan - 12190, Indonesia.

\subsection{Metode Pengumpulan Data}

Populasi yang digunakan mencakup perusahaan manufaktur sektor aneka industri pada sub sektor industri makanan dan minuman yang terdaftar selama 2013-2017 di BEI. Penetapan sampel menggunakan metode purposive sampling yaitu teknik dengan mempertimbangkan sampel tertentu (Sugiyono 2018, 126) dengan penetapan syarat berikut ini: (1) perusahaan sub sektor industri makanan dan minuman dengan laba positif selama periode pengamatan; dan (2) perusahaan menyediakan informasi yang lengkap yang bersumber dari laporan tahunan dan laporan keuangan. Sampel penelitian ditetapkan sebanyak 11 (sebelas) perusahaan.

\section{Tabel 1.Data Sampel Perusahaan}

\begin{tabular}{|c|c|l|}
\hline No & Tanggal IPO & \multicolumn{1}{c|}{ Nama Emiten } \\
\hline 1 & $09-$ Jul-1996 & PT.Wilmar Cahaya Indonesia, Tbk. \\
\hline 2 & $12-$-Feb-1984 & PT.Delta Djakarta, Tbk. \\
\hline 3 & $07-$-kt-2010 & PT.Indofood CBP Sukses Makmur, Tbk. \\
\hline 4 & $14-J u l-1994$ & PT.Indofood Sukses Makmur, Tbk. \\
\hline 5 & $17-J a n-1994$ & PT.Multi Bintang Indonesia, Tbk. \\
\hline 6 & $04-J u l-1990$ & PT.Mayora Indah, Tbk. \\
\hline 7 & $28-J u n-2010$ & PT.Nippon Indosari Corporindo, Tbk. \\
\hline 8 & $28-S e p-2012$ & PT.Sekar Bumi, Tbk. \\
\hline 9 & $08-S e p-1993$ & PT.Sekar Laut, Tbk. \\
\hline 10 & $16-$ Des-1996 & PT.Siantar Top, Tbk. \\
\hline 11 & $02-J u l-1990$ & PT.Ultrajaya Milk Industry, Tbk. \\
\hline
\end{tabular}




\section{Buana Akuntansi}

Yuni dan Ridwan

Vol. 5 No. 2

ISSN 2528-1119

E-ISSN 2580-5452

Sumber: Data BEI (2018)

Total pengamatan yang dilakukan untuk tahun 2013-2017 yaitu 55 data perusahaan.

\subsection{Operasionalisasi Variabel}

Variabel penelitian ini menggunakan proksi, perhitungan rasio keuangan dan penetapan skala dengan tabulasi berikut ini.

Tabel 2.Variabel Operasional

\begin{tabular}{|c|c|c|c|}
\hline Variabel & Proksi & Ukuran Rasio & Skala \\
\hline $\mathrm{Y}$ & Profit Growth & 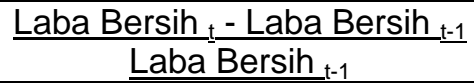 & Rasio \\
\hline $\mathrm{X} 1$ & Quick Ratio & $\frac{\text { Aset Lancar - Persediaan }}{\text { Utang Lancar }}$ & Rasio \\
\hline $\mathrm{X} 2$ & $\begin{array}{c}\text { Debt-to Equity } \\
\text { Ratio }\end{array}$ & $\frac{\text { Total Utang }}{\text { Total Ekuitas }}$ & Rasio \\
\hline X3 & $\begin{array}{c}\text { Total Asset } \\
\text { Turnover }\end{array}$ & $\frac{\text { Penjualan Bersih }}{\text { Total Aset }}$ & Rasio \\
\hline X4 & $\begin{array}{l}\text { Net Profit } \\
\text { Margin }\end{array}$ & $\frac{\text { Laba Bersih }}{\text { Penjualan Bersih }}$ & Rasio \\
\hline
\end{tabular}

\subsection{Metode Analisis Data}

Metode analisis data menggunakan teknik analisis regresi data panel. Teknik ini merupakan analisis regresi yang didasarkan pada data panel untuk mengamati hubungan antar satu variabel terikat (dependent variable) dengan satu maupun lebih dari satu variabel bebas (independentvariable) (Iqbal 2015). Estimasi pemodelan atas regresi data panel dapat dilakukan dengan 3 (tiga) teknik atau pendeketan antara lain: (1) Pooling Least Square atau Common Effect Model (CEM); (2) Fixed Effect Model (FEM); dan (3) Random Effect Model (REM). Ketiga teknik (model) estimasi data panel pada dasarnya dapat ditetapkanberdasarkan keadaan penelitian, namun terdapat cara atau teknik untuk memilih yang paling tepat dalam parameter teknik estimasi data panel yaitu: (1) Uji Chow (Uji Statistik F); (2) Uji Hausman; dan (3) Uji Lagrange Multiplier (LM). Uji linieritas penelitian ini menggunakan teknik Ramsey RESET Test atau disebut dengan general test of spesification.Pengolahan data panel pada penelitian ini menggunakan bantuan program Eviews 9. Untuk mengintepretasikan uji hipotesis secara parsial (t-test)terlebih dahulu menentukan nilai a dan degree of freedom (df) dan membandingkan nilai t-hitung dengan t-tabel. Probabilitas signifikansi dalam penelitian menggunakan tingkat 0,05 dengan kriteria penerimaan hipotesis yaitu jika nilai t-hitung lebih besar dari t-tabel $\left(\mathrm{H}_{0}\right.$ diterima), atau sebaliknya jika nilai t-hitung lebih kecil dari t-tabel ( $\mathrm{H}_{\mathrm{a}}$ diterima).

\section{Analisis dan Pembahasan}

\subsection{Statistik Deskriptif}

Statistik deskriptif atas kinerja keuangan atas pertumbuhan laba perusahaan manufaktur pada sub sektor industri makanan dan minuman di BEI pada periode 2013-2017. 


\section{Buana Akuntansi}

Tabel 3.Hasil Statistik Deskriptif Variabel Penelitian

\begin{tabular}{|c|c|c|c|c|c|}
\hline & $\mathbf{Y}$ & X1 & X2 & X3 & X4 \\
\hline Mean & 0.362345 & 1.695509 & 0.967491 & 1.425073 & 0.101545 \\
\hline Median & 0.194000 & 1.264000 & 1.025000 & 1.283000 & 0.078000 \\
\hline Maximum & 3.587000 & 7.357000 & 3.029000 & 3.057000 & 0.390000 \\
\hline Minimum & -0.554000 & 0.371000 & 0.171000 & 0.546000 & 0.011000 \\
\hline Std. Dev. & 0.657209 & 1.374193 & 0.525029 & 0.611023 & 0.090070 \\
\hline Skewness & 2.650316 & 2.313507 & 0.914244 & 0.952336 & 1.807047 \\
\hline Kurtosis & 12.55279 & 8.824766 & 5.585326 & 3.291346 & 5.620034 \\
\hline Jarque-Bera & 273.5163 & 126.8143 & 22.97919 & 8.508174 & 45.66433 \\
\hline Probability & 0.000000 & 0.000000 & 0.000010 & 0.014206 & 0.000000 \\
\hline Sum & 19.92900 & 93.25300 & 53.21200 & 78.37900 & 5.585000 \\
\hline Sum Sq. Dev. & 23.32386 & 101.9739 & 14.88541 & 20.16083 & 0.438080 \\
\hline Observations & 55 & 55 & 55 & 55 & 55 \\
\hline
\end{tabular}

Sumber: Output Keuangan Eviews 9 (2019)

\subsection{Pemilihan Model Regresi Data Panel}

Pemilihan model regresi data panel dapat dilakukan menggunakan 3 (tiga) pendekatan.

\begin{tabular}{ccc}
\multicolumn{2}{c}{ Tabel 4.Rangkuman Hasil Uji Regresi Data Panel } \\
\hline Metode & Model Estimasi yang Diuji & Hasil / Keputusan \\
\hline Uji Chow (uji statistik F) & CEM vs FEM & Common-Effect Model \\
\hline Uji Hausman & CEM vs REM & Random-Effect Model \\
\hline Uji Lagrange Multiplier (LM) & FEM vs REM & Common-Effect Model \\
\hline Sumber: Data diolah Eviews 9 $(2019)$ &
\end{tabular}

Hasil uji Chow, Hausman dan Lagrange Multiplier menghasilkan keputusan pemilihan Common-Effect pada uji Chow yang dikonfirmasikan ulang melalui uji lagrange multiplier (LM). Oleh karena itu, pengujian hipotesis dengan analisis regresi data panel lebih tepat menggunakan model common effect pada penelitian ini.

\subsection{Uji Asumsi Klasik}

Uji asumsi klasik dilakukan melalui 4 (empat) tahapan, yaituUji normalitas dilakukan dengan melihat nilai Jarque-Bera pada tampilan histogram. 


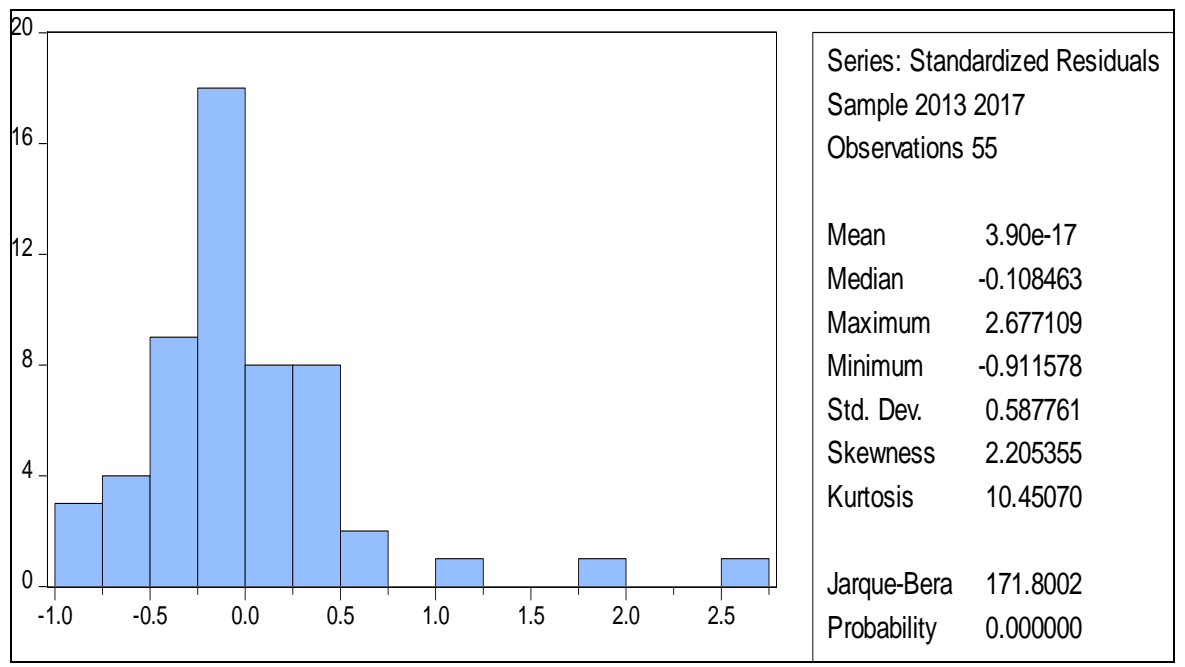

Sumber: Output Pengolahan Eviews 9 (2019)

\section{Gambar 2:Histogram Uji Normalitas}

Hasil uji normalitas menghasilkan nilai Jarque-Berasebesar 171,8002 dengan probabilitas kurang dari $(<)$ 0,05 sehingga signifikan (menolak H0). pada taraf keyakinan 95\%, artinyanilai residual tidak memenuhi asumsi normalitas data. Salah satu kelebihan dari penggunaan data panel yaitu dapat mengurangi bias yang ditimbulkan oleh agregasi data individu dengan pendekatanOrdinary Least Square (OLS), tidak semua uji tersebut harus dilakukan pada model regresi data panel(Basuki dan Prawoto 2016, 296-297). Uji multikolinearitas dilakukan dengan melihat nilai centered ofvariance inflation factors (VIF).

Tabel 5.Hasil Uji Multikolinearitas

\begin{tabular}{cccc}
\hline & \multicolumn{3}{c}{ Variance Inflation Factors } \\
\hline Variable & $\begin{array}{c}\text { Coefficient } \\
\text { Variance }\end{array}$ & $\begin{array}{c}\text { Uncentered } \\
\text { VIF }\end{array}$ & $\begin{array}{c}\text { Centered } \\
\text { VIF }\end{array}$ \\
\hline \hline C & 0.168722 & 24.77189 & NA \\
X1 & 0.008970 & 6.228007 & 2.441766 \\
X2 & 0.048400 & 8.573915 & 1.922866 \\
X3 & 0.020914 & 7.362247 & 1.125590 \\
X4 & 1.221970 & 3.280464 & 1.429335 \\
\hline \hline
\end{tabular}

Sumber: Output Pengolahan Eviews 9 (2019)

Hasil uji multikolinearitas menghasilkan menghasilkan skorvariance inflation factors (VIF)menghasilkanmasing-masing skor atas variabel independen yang kurang dari nilai 10 sehingga tidak terdapat gejala multikolinearitas antar variabel independen. Uji heteroskedastisitas dilakukan dengan teknik persamaan uji wald.

\section{Tabel 6.Hasil Uji Heteroskedastisitas}




\section{Buana Akuntansi}

Yuni dan Ridwan

Vol. 5 No. 2

ISSN 2528-1119

E-ISSN 2580-5452

\begin{tabular}{|c|c|c|c|}
\hline \multicolumn{3}{|c|}{$\begin{array}{l}\text { Wald Test: } \\
\text { Equation: Untitled }\end{array}$} & \multirow[b]{2}{*}{ Probability } \\
\hline Test Statistic & Value & df & \\
\hline t-statistic & -1.197667 & 50 & 0.2367 \\
\hline F-statistic & 1.434405 & $(1,50)$ & 0.2367 \\
\hline Chi-square & 1.434405 & 1 & 0.2310 \\
\hline
\end{tabular}

Sumber: Output Pengolahan Eviews 9 (2019)

Hasil uji heteroskedastisitas dengan teknikuji Waldmenghasilkannilai probabilitas Fstatistics yang sangat tidak signifikan yaitu 0,2367 , dimana hasilnya lebih besar dari0,05. Dengan demikian, model regresi tidak menghasilkan persamaan regresi yang bias atau tidak mengandung gejala heteroskedastisitas. Uji autokorelasi dilakukan dengan pendekatanBreuschGodfrey Serial Correlation Langrange Multiplier (LM).

Tabel 7. Hasil Uji Autokorelasi

\begin{tabular}{llll}
\hline \multicolumn{3}{l}{ Breusch-Godfrey Serial Correlation LM Test: } & \\
\hline \hline F-statistic & 0.701283 & Prob. F(5,45) & 0.6254 \\
Obs*R-squared & 3.975821 & Prob. Chi-Square(5) & 0.5529 \\
\hline \hline
\end{tabular}

Sumber: Output Pengolahan Eviews 9 (2019)

Berdasarkan hasil uji autokorelasi menggunakan pendekatanBreusch-Godfrey Serial Correlation LMmenghasilkannilai Probabilitas Chi-Squarediperoleh sebesar 0,6254> 0,05, maka H0 diterima. Dengan demikian, pada tingkat keyakinan $95 \%$ model regresi tidak terdapat gejala autokorelasi serial.

\subsection{Uji Hipotesis}

Pemilihan model ditetapkan menggunakan common-effect model (CEM) pada uji sebelumnya yang diturunkan ke model penelitian ini.

Tabel 8. Hasil Uji Common-Effect Model (CEM)

\begin{tabular}{lllll}
\hline \hline Variable & Coefficient & Std. Error & t-Statistic & Prob. \\
\hline \hline C & -0.491969 & 0.410773 & -1.197667 & 0.2367 \\
QR & -0.019830 & 0.094699 & -0.209404 & 0.8350 \\
DER & 0.099683 & 0.219976 & 0.453154 & 0.6524 \\
TAT & 0.460211 & 0.144603 & 3.182587 & 0.0025 \\
NPM & 1.335959 & 1.105053 & 1.208955 & 0.2324 \\
\hline \hline R-squared & 0.196895 & Mean dependent var & 0.362345 \\
Adjusted R-squared & 0.132646 & S.D. dependent var & 0.657209
\end{tabular}




\section{Buana Akuntansi}

\begin{tabular}{llll} 
S.E. of regression & 0.612071 & Akaike info criterion & 1.942569 \\
Sum squared resid & 18.73152 & Schwarz criterion & 2.125054 \\
Log likelihood & -48.42066 & Hannan-Quinn criter. & 2.013138 \\
F-statistic & 3.064582 & Durbin-Watson stat & 1.742138 \\
Prob(F-statistic) & 0.024650 & & \\
\hline \hline
\end{tabular}

Sumber: Output Pengolahan Eviews 9 (2019)

Hasil estimasi regresi data panel untuk common-effect model (CEM) pada tingkat alpha $(\alpha=$ $0,05)$ dirangkum sebagai berikut:

Nilai Adjusted $R^{2} \quad: 0,132646$

Nilai probabilitas F : 0,024650 (signifikan)

Nilai probabilitas QR : 0,8350 (tidak signifikan)

Nilai probabilitas DER : 0,6524 (tidak signifikan)

Nilai probabilitas TAT : 0,0025 (signifikan positif)

Nilai probabilitas NPM : 0,2324 (tidak signifikan)

Nilai Adjusted $R$ Squared menunjukkan seberapa besar variabel bebas mampu menjelaskan varian atas variabel terikat. Hasil analisis model regresi data panel secara keseluruhan menghasilkan nilai Adjusted $R^{2}$ sebesar 0,132646 yang menunjukkan bahwa variabel bebas Quick Ratio (QR), Debt-to Equity Ratio (DER); Total Asset Turnover (TAT); danNet Profit Margin (NPM) hanya mampu menjelaskan pertumbuhan laba sebagai variabel terikat sebesar 13,26\% sedangkan sisanya sebesar $86,74 \%$ dipengaruhi oleh variabel lainnya yang tidak diikusertakan pada penelitian ini.

Pembuktian uji hipotesis atas variabel rasio keuangan yang menggunakan pool least squaretest pada 11 (sebelas) perusahaan sub sektor makanan dan minuman yang listing di BEI periode 2013-2017 yaitu:

Hipotesis ke-1: $\quad$ nilai t-statistics untuk variabel quick ratio (QR) diperoleh sebesar -0,209404 dengan probabilitas signifikansi sebesar 0,8350. Nilai probabilitas signifikansi sebesar 0,8350 lebih besar dari a =0,05 sehingga menolak $\mathbf{H}_{\mathbf{1}}$. Hipotesis ini secara statistik tidak membuktikan quick ratio sebagai rasio likuiditas berpengaruh signifikan atas pertumbuhan laba.

Hipotesis ke-2: nilai t-statistics untuk variabel debt-to equity ratio (DER) diperoleh sebesar 0,453154 dengan probabilitas signifikansi sebesar 0,6524. Nilai probabilitas signifikansi sebesar 0,6524 lebih besar dari a =0,05 sehingga menolak $\mathbf{H}_{2}$. Hipotesis ini secara statistik tidak membuktikan debt-to equity ratio sebagai rasio solvabilitas berpengaruh signifikan atas pertumbuhan laba.

Hipotesis ke-3: nilai t-statistics untuk variabel total asset turnover (TAT) diperoleh sebesar 3,182587 dengan probabilitas signifikansi sebesar 0,0025. Nilai probabilitas signifikansi sebesar 0,0025 lebih kecil dari a = 0,05 sehingga menerima $\mathbf{H}_{3}$. Hipotesis ini secara statistik membuktikan total asset turnover sebagai rasio aktivitas berpengaruh positif dan signifikan atas pertumbuhan laba.

Hipotesis ke-4: nilai t-statistics untuk variabel net profit margin (NPM) diperoleh sebesar 1,208955 dengan probabilitas signifikansi sebesar 0,2324. Nilai probabilitas signifikansi sebesar 0,2324 lebih besar dari a =0,05 sehingga menolak $\mathbf{H}_{4}$. 


\section{Buana Akuntansi}

Hipotesis ini secara statistik tidak membuktikan net profit margin sebagai rasio profitabilitas berpengaruh signifikan atas pertumbuhan laba.

\subsection{Pembahasan}

Penggunaan rasio keuangan untuk mengukur kinerja keuangan yang terdiri dari rasio likuiditas, rasio solvabilitas, rasio aktivitas dan rasio profitabilitas dengan pengukuran masingmasing quick ratio, debt-to equity ratio, total asset turnover, net profit margin dan profit growth sebagai variabel dampak pertumbuhan laba cukup akurat dan membuktikan signalling theory (teori pensinyalan) bagi calon investor atau publik untuk menganalisis dan menginterpretasi rasio keuangan sebagaidasar pengambilan keputusan investasi, hasil ini dibuktikan dengan nilai probabilitas F-statistics sebesar 0,024650 lebih kecil dibandingkan dengan $\alpha=5$ persen sehingga secara statistik membuktikan bahwa kinerja keuangan secara simultan berpengaruh signifikan atas pertumbuhan laba.

Rasio likuiditas dengan pengukuran quick ratio melalui pembuktian hipotesis ke-1 menunjukkan bahwa tidak adanya pengaruh signifikan quick ratio terhadap pertumbuhan laba. Ketidakmampuan quick ratio mempengaruhi pertumbuhan laba dimungkinkan karena aset lancar yang paling likuid seperti surat berharga yang berkualitas buruk dapat mengakibatkan nilai jualnya dibawah nilai nominalnya dan piutang bermutu rendah sehingga tidak dapat ditagih. Akibatnya perusahaan tidak memiliki kemampuan dalam menyelesaikan utang lancar.Ketidakmampuan perusahaan membayar utang lancarnya mengindikasikan perusahaan mengalami penurunan laba atau bahkan mengalami kerugian. Temuan penelitian mengkonfirmasi hasil quick ratio yang tidak berpengaruh secara signifikan atas pertumbuhan laba (Khaldun dan Muda 2014).

Rasio solvabilitas dengan pengukuran debt-to equity ratio melalui pembuktian hipotesis ke-2 menunjukkan bahwa tidak adanya pengaruh signifikan debt-to equity ratio terhadap pertumbuhan laba. Ketidakmampuan debt-to equity ratio mempengaruhi pertumbuhan laba dikarenakan rasio ini cukup tinggi yang menunjukkan kepemilikan proposi modal lebih kecil dibandingkan dengan utang perusahaan sehingga adanya ketergantungan yang tinggi terhadap pihak eksternal. Kondisi ini dapat diidentifikasi bahwa adanya kenaikan utang perusahaan sebagai modal kerja dalam kegiatan operasional tidak mampu menghasilkan keuntungan perusahaan secara optimal sehingga perubahan debt-to equity ratio(DER) tidak memiliki pengaruh untuk dapat meningkatkan kinerja atau laba perusahaan secara signifikan. Temuan penelitian mengkonfirmasi hasil DER yang tidak berpengaruh secara signifikan atas pertumbuhan laba (Djannah 2017).

Rasio aktivitas dengan pengukuran total asset turnover melalui pembuktian hipotesis ke-3 menunjukkan terdapat pengaruh yang signifikan total asset turnover terhadap pertumbuhan laba. Total asset turnover (TAT) berpengaruh signifikan atas pertumbuhan laba dengan arah yang positif, dimana memberikan sinyal positif terhadap investor dalam menginvestasikan dananya. Pertumbuhan laba membuat para manajer menyimpulkan bahwa variabel total asset turnover (TAT) dapat memprediksi pertumbuhan laba. Temuan penelitian mengkonfirmasi hasil total asset turnover berpengaruh positif dan signifikan atas pertumbuhan laba (Erawati dan Widayanto 2016).

Rasio profitabilitas dengan pengukuran net profit margin melalui pembuktian hipotesis ke-4 menunjukkan bahwa tidak adanya pengaruh signifikan net profit margin atas pertumbuhan laba. 


\section{Buana Akuntansi}

Semakin tinggi net profit margin memiliki indikasi bahwa perusahaan memiliki kemampuan dalam meningkatkan usahanya melalui pencapaian laba operasional dalam periode tersebut. Dengan capaian hasil laba ini maka investor mendapatkan sinyal positif atas kinerja perusahaan sehingga investor dapat mengharapkan adanya tingkat pengembalian yang tinggi dari modal yang dimilikinya. Temuan penelitian tidak mengkonfirmasi hasil net profit margin berpengaruh secara signifikan atas pertumbuhan laba (Ayem, Wahyuni dan Suyanto 2017).

\section{Kesimpulan, Keterbatasan, dan Saran}

\subsection{Kesimpulan}

Kesimpulan dari hasil penelitian kinerja keuangan yang mempengaruhi pertumbuhan laba perusahaan pada industri manufaktur sub sektor makanan dan minuman periode 2013-2017 adalah sebagai berikut:

a. Quick ratio $(\mathrm{QR})$ atas rasio likuiditas tidak memiliki pengaruh secara signifikan terhadap pertumbuhan laba, hal ini disebabkan atas ketidakmampuan perusahaan membayar utang lancarnya mengindikasikan perusahaan mengalami penurunan laba atau bahkan mengalami kerugian.

b. Debt-to equity ratio (DER) atas rasio solvabilitas tidak memiliki pengaruh secara signifikan terhadap pertumbuhan laba, hal ini dikarenakan peningkatan utang perusahaan sebagai modal kerja dalam kegiatan operasional tidak mampu menghasilkan keuntungan perusahaan secara optimal.

c. Total asset turnover (TAT) atas rasio aktivitas memiliki pengaruh secara positif dan signifikan terhadap pertumbuhan laba, hal ini dikarenakan pertumbuhan laba memotivasi para manajer mengelola perputaran total asetnyadalam memprediksi pertumbuhan laba.

d. Net profit margin (NPM) atas rasio profitabilitas tidak memiliki pengaruh secara signifikan terhadap pertumbuhan laba, hal ini dikarenakan capaian laba operasional menjadikan sinyal bagi investor yang memiliki kinerja perusahaan yang rendah dalam konteks pertumbuhan laba.

\subsection{Implikasi / Keterbatasan dan Saran}

Penelitian ini memiliki implikasi antara lain:

a. Bagi perusahaan; temuan penelitian ini dapat memberikan masukan penting untuk mengevaluasiperangkat kebijakan akuntansi PSAK No.72 yang diadopsi dari IFRS 15 tentang Akuntansi Pendapatan.

b. Bagi Investor; temuan penelitian ini dapat memberikan masukan penting dan sinyal untuk menentukan portofolio investasi saham pada perusahaan-perusahaan yang bergerak pada sub sektor makanan dan minuman yang terdaftar di BEI sebagai dasar pengambilan keputusan.

c. Bagi Regulator; temuan penelitian ini dapat memberikan masukan bagi Otoritas Jasa Keuangan $(\mathrm{OJK})$ sebagai bahan evaluasi dan monitoring untuk merumuskan kebijakan dalam konteks pertumbuhan laba.

Penelitian ini memiliki keterbatasan antara lain: 


\section{Buana Akuntansi}

a. Hasil uji normalitas yang menghasilkan nilai Jarque-Bera yang signifikan pada tingkat alpha 5 persen sehingga tidak memenuhi asumsi uji normalitas walaupun tidak harus mensyaratkan keseluruhan uji asumsi klasik pada analisis regresi data panel.

b. Penetapan sampel penelitian ini hanya terseleksi 11 perusahaan sub sektor makanan dan minuman yang terdaftar di BEI tahun sehingga hasil penelitian tidak dapat digeneralisasi untuk industri sektor konsumsi dan rumah tangga di Indonesia.

Saran untuk penelitian selanjutnya diantaranya:

a. Periode penelitian dapat diperluas agar mendapatkan data observasi yang lebih banyak dan diharapkan dapat memperbaiki hasil penelitian khususnya uji asumsi klasik sebagai syarat uji hipotesis dalam penelitian multivariat.

b. Subjek penelitian dapat ditambahkan dengan melibatkan perusahaan pada seluruh sektor industri konsumsi dan rumah tangga

c. Objek penelitian dapat dikembangkan dengan menambah pengukuran kinerja keuangan lainnya seperti return on assets (ROA), return on equity (ROE) serta faktor lainnya yang memiliki pengaruh terhadap pertumbuhan laba.

\section{Daftar Pustaka}

Ayem, Sri, Tri Wahyuni, and Suyanto. "Pengaruh Quick Ratio, Debt to Equity Ratio, Inventory Turnover, dan Net Profit Margin terhadap Pertumbuhan Laba Pada Perusahaan Manufaktur yang Terdaftar Di Bursa Efek Indonesia Tahun 2011-2015." Jurnal Akuntansi Dewantara (Universitas Sarjanawiyata Tamansiswa) 1, no. 2 (Oktober 2017): 117-126.

Azmi, Muchamad Ulul, Rita Andini, and Kharis Rahar. "Analisis Pengaruh Net Profit Margin (NPM), Return On Assets (ROA), dan Current Ratio (CR) terhadap Harga Saham Emiten LQ45 yang terdaftar di Bursa Efek Indonesia tahun 2010-2014." Journal of Accounting 2, no. 2 (2016): 1-10.

Basuki, Agus Tri, and Nano Prawoto. Analisis Regresi Dalam Penelitian Ekonomi \& Bisnis: Dilengkapi Aplikasi SPSS \& EVIEWS. Depok: Rajagrafindo Persada, 2016.

Djannah, Raudatul. "Pengaruh Kinerja Keuangan Terhadap Pertumbuhan Laba pada Perusahaan Food and Beverage." Jurnal Ilmu \& Riset Manajemen (Sekolah Tinggi Ilmu Ekonomi Indonesia (STIESIA)) 6, no. 7 (Juli 2017): 1-16.

Endarwati, Oktiani. Industri Makanan dan Minuman Diyakini Terus Cemerlang. April 23, 2018. https://ekbis.sindonews.com/read/1300183/34/industri-makanan-dan-minumandiyakini-terus-cemerlang-1524480979 (accessed Mei 10, 2019).

Erawati, Teguh, and Ignatius Joko Widayanto. "Pengaruh Working Capital To Total Asset, Operating Income To Total Liabilities, Total Asset Turnover, Return On Asset, Dan Return On Equity Terhadap Pertumbuhan Laba Pada Perusahaan Manufaktur Yang Terdaftar Di Bursa Efek Indonesia." JURNAL AKUNTANSI (Universitas Sarjanawiyata Tamansiswa) 4, no. 2 (Desember 2016): 49-60.

Fahmi, Irham. Analisis Laporan Keuangan. Bandung: Alfabeta, 2017.

Harahap, Sofyan Syafri. Analisis Kritis Atas Laporan Keuangan. Jakarta: Rajawali Pers, 2016. Hery. Analisis Kinerja Manajemen (Cetakan Pertama). Jakarta: PT Grasindo, 2015. 
Iqbal, Muhammad. "Regresi Data Panel (2) Tahap Analisis." 2015. https://dosen.perbanas.id/regresi-data-panel-2-tahap-analisis/2015/ (accessed Mei 17, 2019).

Husain, T. "An Analysis of Modeling Audit Quality Measurement Based on Decision Support Systems (DSS)." European Journal of Scientific Exploration (A.O. Syniuta Publisher) 2, no. 6 (December 2019): 1-9.

Husain, T., dan Ade Elza Surachman. "Praktik manajemen laba: Studi komparasi pada perusahaan-perusahaan yang melakukan IPO tahun 2012-2016." Journal Management, Business, and Accounting (MBiA) (DRPM Bina Dharma University) 16, no. 1 (April 2017): 21-30.

Ikatan Akuntan Indonesia (IAI). "Konvensi Nasional Akuntansi (KNA) VI." Peran Akuntan dalam Penataan Ulang Sistem Keuangan Global. Bandung, Agustus 2009.

Kementerian Perindustrian RI. Analisis Perkembangan Industri 2017. Jakarta: Pusat Data dan Industri Kementerian Perindustrian, 2017.

-. "Industri Makanan dan Minuman Masih Jadi Andalan." https://kemenperin.go.id/. Nopember 24, 2017. https://kemenperin.go.id/artikel/18465/Industri-Makanan-dan-MinumanMasih-Jadi-Andalan (accessed Maret 23, 2020).

Kewal, Suramaya Suci. "Pengaruh Inflasi, Suku Bunga, Kurs, dan Pertumbuhan PDB Terhadap Indeks Harga Saham Gabungan." Jurnal Economia 8, no. 1 (April 2012): 53-64.

Khaldun, Khalidazia Ibnu, and Iskandar Muda. "The Influence Of Profitability And Liqudity Ratios On The Growth Of Profit Of Manufacturing Companies." International Journal of Economics, Commerce and Management (The Pennsylvania State University) II, no. 12 (December 2014): 1-17.

Kusumastuti, Wahyu Fitri, Erma Setiawati, and Andy Dwi Bayu Bawono. "Pengaruh Profitabilitas Dan Struktur Terhadap Nilai Perusahaan Dengan Kepemilikan Manajerial Sebagai Variabel Moderasi (Studi Pada Perusahaan Property dan Real Estate Yang Terdaftar Di Bursa Efek Indonesia Tahun 2015-2017)." Seminar Nasional dan The 6th Call For Syariah Paper (SANCALL). Semarang: LPPI UMS, 2016. 275-295.

Mahaputra, I Nyoman Kusuma Adnyana. "Pengaruh Rasio-Rasio Keuangan terhadap Pertumbuhan Laba pada Perusahaan Manufaktur yang terdaftar di BEI." Jurnal Akuntansi dan Bisnis (Faculty of Economics and Business, Udayana University) 7, no. 2 (Juli 2012).

Malau, Erisa, and Potak Parhusip. "Pengaruh Asimetri Informasi dan Ukuran Perusahaan Terhadap Manajemen Laba Perusahaan Food Dan Beverages Yang Go Public Di Bursa Efek Indonesia." JRAK 2, no. 1 (Maret 2016): 83-106.

Munte, Mei Hotma Mariati, and Thioly Theresia Sitanggang. "Pengaruh Rasio Keuangan Terhadap Pertumbuhan Laba Pada Industri Manufaktur Yang Terdaftar Di Bursa Efek Indonesia." 5, no. 1 (Desember 2015).

Natalia, Debby, and Eko PudjoLaksono. "Pengaruh Mekanisme Good Corporate Governance Terhadap Praktik Earning Management Badan Usaha Perbankan." Calyptra: Jurnal Ilmiah Mahasiswa Universitas Surabaya 2, no. 1 (2013): 1-18.

Rachmawati, Anggun Arif dan Nur Handayani. "Pengaruh Rasio Keuangan dan Kebijakan Dividen Terhadap Pertumbuhan Laba pada Perusahaan Manufaktur yang Terdaftar di BEI." Jurnal Ilmu E Riset Akuntasnsi 3, no. 3 (2014): 1-15. 
Subramanyam, K.R. Financial Statement Analysis. 11th International Edition. New York: McGraw-Hill., 2014.

Sugiyono. Metode Penelitian Evaluasi: Pendekatan Kuantitatif, Kualitatif, dan Kombinasi. Bandung: CV. Alfabeta, 2018

Yanti, Puji Isyanto, dan Mohd Haizam Mohd Saudi. "Analysis of Financial Performance with Using Economic Value Added." International Journal of Psychosocial Rehabilitation, no. 7 (2020): 3362-3370. 